\title{
Hero Types, Roller Coasters, and Dark Zones
}

\author{
HOW CAN ADVISERS MANAGE CLIENTS' EMOTIONAL REACTIONS TO MARKET STRESS?
}

By Ed McCarthy

In a perfect world, investors would always act rationally. When people are faced with dramatic public events or unexpected personal setbacks, however, emotions come to the surface that can affect their judgment. Identifying a client's emotional profile and understanding how those emotions influence financial decisions can help advisers keep the client on course through difficult times.

For Chris White, CFA, senior portfolio manager

Knowledge of clients' and advisers' distinct personality types can help protect investors from making poor decisions during a crisis.

There are three "hero types" (fixer, survivor, and protector) that manifest differently in each situation.

Recognizing cognitive, emotional, and social biases can help clients and advisers change their behavior. with Hemenway Trust Company in Salem, New Hampshire, an interest in understanding the emotional aspects of clients' behavior during uncertain times started in the early 1990s after he read published research on loss aversion. He combined that interest with an examination of how early childhood experiences play a formative role in determining personality types and financial behavior in adulthood. White cites the work of psychologist David Kantor, founder of the Kantor Institute and a former professor at Harvard Medical School, as a key influence on the approach he details in his recently co-authored book (with Richard Koonce), Working with the Emotional Investor: Financial Psychology for Wealth Managers.

Kantor classifies personalities into three "hero types": fixer, survivor, and protector. White adopts that nomenclature and says it is critical for us to understand what type we, as advisers, are, as well as what types our clients are.

The emotions each hero type exhibits depend on the circumstances, which White breaks into three "zones" determined by the stakes involved. Low-stakes events are placed in the light zone, middling-stakes events in the intermediate zone, and high-stakes events in the dark zone. From a financial perspective, a bull market would be in the light zone and a market crash like the one in 2008-2009 would be in the dark zone.

Hero types, White explains, respond in a pattern for each zone that advisers need to recognize. And the behaviors for each type in each zone differ widely. Figure 1 summarizes each type's behavior in each zone.

White gives an example of survivor behavior and how it can become problematic in the high-stakes dark zone. "They are so focused on just soldiering on through thick and thin that they're likely not to make changes to their portfolio, even when, in fact, it would be advisable," he says. "They're likely to throw good money after bad," he continues, "because for them it's the cause that's more important than anything else, even to the point where they can abandon those people around them because they're so focused on soldiering on."

White's book provides guidance for advisers on how to recognize their own and their clients' hero types, and he shares insights on building successful relationships between each group. Those insights and skills will prove valuable when clients encounter dark zones, he maintains. "We each have our strengths and our weaknesses, but in the dark zone, those weaknesses really come to the fore," he says. "As the adviser, it's important to be aware of that potential market behavior."

Clients and advisers also present identifiable social engagement styles, which White categorizes as closed, open, and random. Closed-style clients seek professional credibility and expertise in the subject matter from their advisers. They are "cut-to-the-chase" clients, he observes. "Opens" value input from multiple sources, with back-and-forth discussions. They make decisions deliberately and focus on the process of effective decision making with their advisers. As the name implies, "randoms" value creativity and spontaneity of expression. They can appear unfocused and have difficulty making decisions, which requires the adviser to bring structure to client conversations.

\section{RIDING THE ROLLER COASTER}

Research has shown that retail investors are prone to buy high and sell low. That behavior results at least partly from a lack of long-term perspective. Investors often focus on short-term investment performance, a myopic view often reinforced by the financial news media.

A short-term perspective can create an emotional roller coaster for investors, as detailed in a 2013 Barclays white paper titled "Overcoming the Cost of Being Human," which illustrates how emotional states vary in response to investment performance through a bull market, bear market, and subsequent recovery, including investors' tendency to buy at market tops ("exuberance") and sell near market bottoms ("capitulation").

\section{PROFILING EMOTIONS FOR BETTER BEHAVIOR}

Advisers may know about this response pattern but wonder whether clients can be helped to avoid emotionally based investment decisions. Achieving that result was one motivation for Barclays' development and adoption of its proprietary Financial Personality Assessment ${ }^{\mathrm{TM}}$.

Peter Brooks, head of behavioral finance for Barclays 
FIGURE 1

\section{TYPICAL HERO-TYPE BEHAVIOR BY ZONE}

\begin{tabular}{llll}
\hline Fixer & $\begin{array}{l}\text { Light Zone } \\
\text { Charming, } \\
\text { magnetic, } \\
\text { charismatic, } \\
\text { focused }\end{array}$ & $\begin{array}{l}\text { Intermediate Zone } \\
\text { oriented }\end{array}$ & $\begin{array}{l}\text { Dark Zone } \\
\text { Dantrolling, } \\
\text { dictatorial }\end{array}$ \\
\hline Survivor & $\begin{array}{l}\text { Cause centric, } \\
\text { committed, } \\
\text { purposeful }\end{array}$ & $\begin{array}{l}\text { Persevering, } \\
\text { enduring, stoic }\end{array}$ & $\begin{array}{l}\text { Self-sacrificing, } \\
\text { obsessive, } \\
\text { "martyr-like" }\end{array}$ \\
\hline Protector & $\begin{array}{l}\text { Protective of others, } \\
\text { caring/shielding, } \\
\text { other directed }\end{array}$ & $\begin{array}{l}\text { Anticipating threats } \\
\text { and dangers, risk } \\
\text { averse }\end{array}$ & $\begin{array}{l}\text { Sense of powerless- } \\
\text { ness, vengeful, } \\
\text { "acts the victim" }\end{array}$ \\
& & & .
\end{tabular}

Low Stakes

High Stakes

Source: White and Koonce, Working with the Emotional Investor.

Wealth and Investment Management in London, says his team created the Assessment's questionnaire in late 2006. The material goes beyond the usual risk profile, he explains: "Risk tolerance doesn't feel like it's enough in order to fully understand the investor and their attitudes. So, we did an awful lot of primary research to understand what other dimensions of people's personalities or their preferences might actually be really important for how satisfied they are with their investing, how likely they are to make the investment decision, how confident they feel. And because of that, we developed our client profiling tool."

The Assessment asks clients to agree or disagree with 36 statements. The measured dimensions include risk tolerance, composure, market management, perceived financial expertise, desire for delegation, and belief in skill. "There are dimensions that focus on long-term risk attitude-the ones you would expect, the risk tolerance dimension," says Brooks. "There are also dimensions that deal with very short-term reactions to anxiety and stress, which we measure through our composure dimension, [or] the nervousness with making that initial investment and engaging with financial markets, which we assess through market engagement."

The remaining dimensions profile financial decision making: How much confidence do the investors have in their decisions? Do they want to delegate financial decisions? Do they believe investment managers are skilled, and is that skill worth the cost? There are no right or wrong answers, Brooks says, but the resulting scores let the firm design portfolios that can help protect investors from making poor decisions in times of stress and anxiety.

For example, for a client with a low market-engagement score,

it might be prudent to start with dollar-cost averaging to overcome the client's reluctance to take on risk. Another approach could be to build out the risk-free and low-risk portfolio allocations first instead of making all investments immediately.

The composure measure helps advisers anticipate which clients are likely to experience higher levels of stress during unexpected market turmoil. Contacting those clients quickly to share the bank's perspective can help reassure them and keep them on track. Alternatively, clients with high composure levels and large cash balances might be willing to consider new investments in the same market environment.

\section{A BIASED APPROACH}

Investors bring cognitive biases to their investment decisions, says H. Kent Baker, CFA, professor of finance at the Kogod School of Business at American University in Washington, DC. He describes three broad categories of biases: cognitive biases, or biases in how people think; emotional biases, which affect how people behave or react; and social biases, which take place on a larger-than-individual scale.

Baker, who is co-author of Investment Traps Exposed: Navigating Investor Mistakes and Behavioral Biases, says that developing an investment policy statement for a client and then periodically reviewing the portfolio allocation against possible investment scenarios is an effective method to help illuminate biases and anticipate behaviors. He cites the example of posing a hypothetical substantial market decline to learn which clients would want to sell their assets at a loss. "One of the best things that advisers can do is to have that discussion with the particular clients before these types of events occur so they can begin to gauge how the client may respond and also provide some feedback," he says.

An adviser's role is to recognize biases, including their own, and bring them to clients' attention. That awareness is the first step in effecting change, says Baker, and providing case studies or sharing professional experiences shows clients how biases influence their decisions. But Baker acknowledges that recognizing a bias and admitting to it does not guarantee changed behavior. For instance, everyone knows that smoking and being overweight are bad for one's health, but both problems persist. Changing certain habits can be difficult because it requires people to change behavior patterns, which Baker notes is exceptionally hard to do.

\section{DÉJÀ VU?}

Twenty years ago, Alan Greenspan coined his famous "irrational exuberance" phrase. Some market commentators believe that with equity valuations relatively high and interest rates starting to rise, we have entered that stage again. If those prognostications are correct, now is a good time to prepare for clients' behaviors in times of market stress.

"Know Your Client-Or Else," CFA Institute Magazine (December 2016) [www.cfapubs.org]

"A More Personalized Approach to Private Wealth," Enterprising Investor (30 July 2015) [blogs.cfainstitute.org]
Ed McCarthy is a freelance financial writer in Pascoag, Rhode Island. 